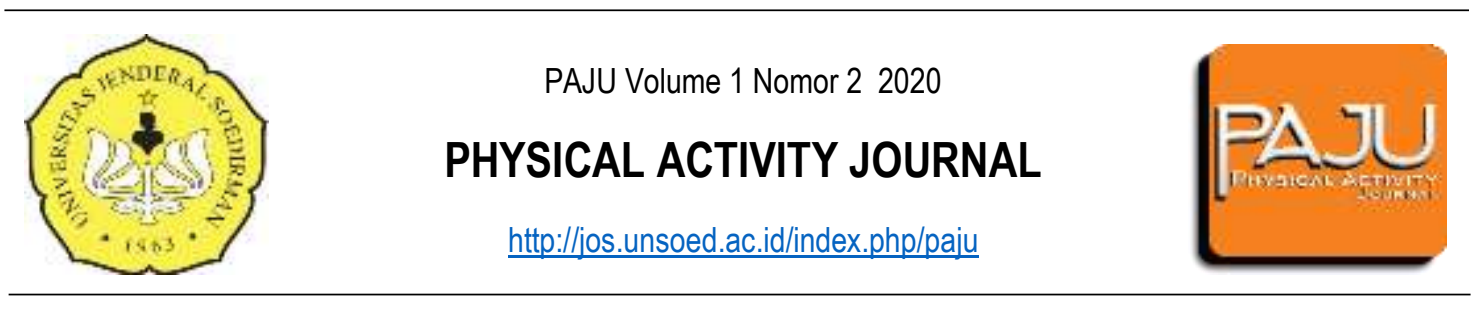

\title{
Identifikasi Keberbakatan Olahraga Metode Australian Sport Search Pada Anak Sekolah Dasar
}

\author{
Muhamad Syafei ${ }^{1}$, Didik Rilastiyo Budi², Mohammad Nanang Himawan Kusuma ${ }^{3}$, Arfin Deri Listiandi ${ }^{4}$ \\ 1,2,3,4 Prodi Penjas Fakultas IImu-IImu Kesehatan, Universitas Jenderal Soedirman, Indonesia \\ email: muh.syafeimaulana.unsoed@gmail.com¹, didik.rilastiyo.budi@unsoed.ac.id², anangkusuma@yahoo.com³, \\ arfinderilistiandi@gmail.com ${ }^{4}$ \\ DOI: https://doi.org/10.20884/1.paju.2020.1.2.2285
}

\begin{abstract}
Abstrak
Identifikasi keberbakatan olahraga merupakan salah satu faktor penting dalam proses pembinaan prestasi, akan tetapi tahapan tes dan pengukuran identifikasi keberbakatan olahraga masih jarang dilakukan terutama di tingkat daerah. Tujuan Penelitian ini yaitu untuk mengetahui keberbakatan olahraga pada anak Sekolah Dasar kelas V dengan menggunakan metode analisis keberbakatan Australian Sport Search. Jumlah sampel penelitian sebanyak 100 anak dari berbagai sekolah di Banyumas. Penelitian menggunakan metode deskriptif expostfacto. Hasil menunjukan bahwa dari 100 anak Sekolah Dasar yang menjadi sampel penelitian tingkat keberbakatan anak menunjukan bahwa sebanyak 43 anak menunjukan berbakat dalam bidang olahraga dan 57 anak tidak berbakat dalam bidang olahraga. Selain itu dari 100 orang anak menunjukan bahwa 22 anak berbakat pada cabang olahraga atletik, 9 anak menunjukan berbakat di sepak bola, 5 anak cabang olahraga beladiri dan yang lainnya berbakat di cabang olahrga bola basket, bola tangan, bulutangkis dan softball/baseball. Berdasarkan hasil tersebut maka perlu adanya program pemanduan bakan olahraga secara khusus bagi anak usia pelajar, sehingga dapat mengidentifikasi bakat anak sedini mungkin.
\end{abstract}

Kata Kunci : Keberbakatan Olahraga, Australian Sport Search, Anak Sekolah Dasar

\begin{abstract}
The talent identification of sport is an important factor in the process of fostering achievement, but the stages of the test and measurement of sporting giftedness identification are still rarely done, especially at the regional level. The purpose of this study is to determine the giftedness of sports in elementary school class $V$ children using the Australian Sport Search giftedness analysis method. The number of research samples were 100 children from various schools in Banyumas. The study used a descriptive ex-postfacto method. The results showed that out of 100 elementary school children who took part in the research of children's giftedness showed that as many as 43 children showed talent in sports and 57 children were not gifted in sports. In addition, out of 100 children showed that 22 children were gifted in athletics, 9 children showed talent in soccer, 5 were in martial arts and others were in basketball, handball, badminton and softball/baseball. Based on these results, it is necessary to have a sports training program specifically for students of child age, so that children can identify their talents as early as possible.
\end{abstract}

Keywords : Talent Identification, Australian Sport Search, Elementary School Children 


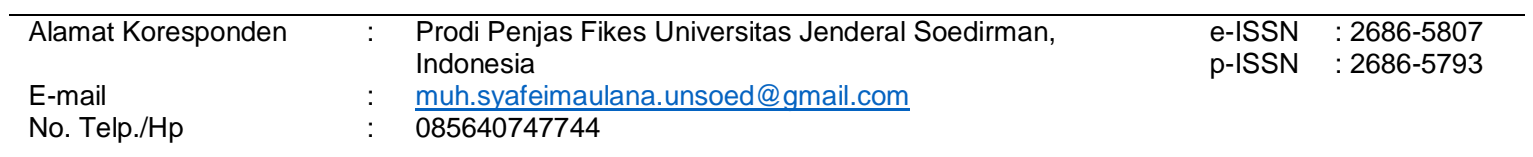

\section{PENDAHULUAN}

Minimnya pengetahuan dan pemahaman dari pembina, pelatih dan instruktur olahraga dalam menghasilkan atlet potensial, dapat berpengaruh pada tidak meningkatnya dan bahkan penurunan prestasi olahraga di tingkat daerah, nasional serta Internasional. Faktor-faktor yang dianggap kurang penting, namum pada perkembangannya dapat memberikan manfaat yang sangat besar untuk prestasi atlet di masa depan, salah satu faktor tersebut yaitu pola dan proses pembinaan prestasi olahraga melalui identifikasi keberbakatan olahraga terhadap anak usia dini. Kusuma, Syafei, \& Budi (2019) menjelaskan bahwa bakat merupakan faktor utama yang lebih menentukan keberhasilan atlet untuk mencapai puncak prestasi di bidang olahraga.

Bakat merupakan faktor penting dalam pencapaian prestasi olahraga, sehingga pada proses perkembangannya harus dilakukan berbagai tes keberbakatan untuk dapat melihat bakat dominan yang dimiliki oleh calon atlet. Indentifikasi keberbakatan olahraga tidak bisa lagi hanya mengandalkan pengamatan dan penilaian subjektif dari pelatih, akan tetapi harus dilakukan dengan cara tes melalui seleksi yang menunjang untuk dapat melihat bakat calon atlet. Kusuma et al. (2019) menjelaskan seleksi bakat adalah komponen yang penting dan harus dilaksanakan untuk mengetahui bakat yang sesuai dari calon atlet, dengan tujuan prestasi puncak. Lebih lanjut, Indarto et al. (2018) menjelaskan peak performent atau prestasi puncak dapat terjadi apabila proses pembinaan bakat olahraga dilaksanakan dengan baik, berdasarkan minat dan bakat kecabangan olahraga yang dimiliki atlet.

Identifikasi keberbakatan kini telah banyak dikembangkan dibeberapa negara. Meskipun metode yang dikembangkan berbeda-beda, tujuan mereka adalah sama untuk menjaring bibit-bibit atlet berbakat yang diprediksi akan dapat bersaing dan berprestasi di masa yang akan datang. Lawrence (2010) dipaparkan alasan pengembangan program identifikasian keberbakatan, bahwa: Identifikasi keberbakatan dirasakan oleh banyak pemerintah sebagai sarana untuk memanfaatkan bakat olahraga bangsa, untuk membawa kesuksesan masa depan di arena internasional. Meskipun metode yang digunakan berbedabeda, akan tetapi memiliki tujuan yang sama, yaitu untuk menemukan atlet berbakat dan potensial secara efektif dan efisien untuk dimaksimalkan melalui pembinaan dengan menggunakan program latihan khusus sesuai dengan kecabangan olahraga yang sesuai untuk pencapaian prestasi puncak di masa datang.

Berdasarkan penjelasan di atas maka identifikasi keberbakatan olahraga penting untuk dilaksanakan, akan tetapi pada praktek di lapangan, program identifikasi keberbakatan belum banyak diterapkan. Kabupaten Banyumas sebagai salah satu daerah yang memiliki tingkat populasi penduduk 
yang tinggi namun belum menghasilkan atau mencetak atlet yang mampu berprestasi di level nasional dan bahkan internasional dengan jumlah yang signifikan, ini terlihat dari data hanya Tantowi Ahmad di cabang olaraga Bulutangkis, Santi di cabang olahraga Panjat Tebing, Rohman Hidayat di cangan Sepak Takraw, selain ketiga nama tersebut belum ada lagi atlet Kabupaten Banyumas yang mampu bersaing di level Nasional, salah satu faktor yang menyebabkan hal ini terjadi karena belum menerapkan pola pembinaan yang sesuai dengan pertumbuhan dan perkembangan anak. Menanggapi fenomena tersebut, maka program identifikasi keberbakatan olahraga penting untuk dilakukan, dijelaskan bahwa talent scouting (pemanduan bakat) adalah sebuah proses awal untuk mengidentifikasi keberbakatan anak dalam hal ini khususnya dibidang olahraga (UU SKN, 2005).

Proses pemanduan bakat olahraga perlu dilakukan dari usia sedini mungkin, sehingga bakatbakat calon atlet dapat ditemukan dengan tepat, sehingga terhindar dari kesalahan dalam pemilihan cabang olahraga. Mengenai hal tersebut, Hidayatullah \& Sapta (2008) menjelaskan pembinaan olahraga prestasi sebaiknya dimulai dari usia dini, sehingga mengurangi terjadinya kesalahan dan harus dilakukan secara berkesinambungan, namun tetap mempertimbangkan kondisi perkembangan anak. Lebih lanjut Arifin et al. (2017) menjelaskan siswa Sekolah Dasar adalah sumber aset untuk memperoleh calon atlet potensial dan berbakat. Sehingga sangat tepat apabila proses identifikasi keberbakatan olahraga dilakukan mulai dari tingkat Sekolah Dasar.

Salah satu metode pemanduan bakat yang dapat dilakukan untuk mengetahui keberbakatan seseorang dan kesesuaian cabang olahraga yaitu dengan menggunakan metode Australian Sport Seacrh, dengan menggunakan metode Australian Sport Seacrh maka dapat diketahui cabang olahraga yang tepat bagi anak, baik cabang olahraga permainan, beladiri, akurasi maupun cabang olahraga terukur. Furqon (2000) memaparkan metode sports search adalah suatu metode pengidentifikasian bakat yang tersiri dari 10 butir tes yang bertujuan membantu anak, untuk menemukan potensi anak dalam olahraga yang disesuaikan dengan karakteristik dan potensi anak. Sports search ini dikembangkan oleh The Australian Commision yang merupakan bagian dari Aussie Sports dengan maksud untuk melakukan pembinaan pada atlet-atlet muda.

\section{METODE}

Penelitian ini menggunakan metode deskriptif ex-postfacto. Sugiyono (2016) menjelaskan bahwa metode ex-postfacto merupakan jenis penelitian yang tidak mempunyai kontrol langsung terhadap variabel. Pada penelitian Identifikasi Keberbakatan Olahraga Populasi adalah siswa kelas V Sekolah Dasar di Kabupaten Banyumas. Sampel pada penelitian ini adalah siswa Sekolah Dasar kelas V di Kabupaten Banyumas dengan jumlah 6 Sekolah, Sekolah tersebut yaitu SDN 2 Karangduren, SDN 5 Teluk, SDN Kediri Karanglewas, SDN 1 Bantarsoka, SDN 2 Purwokerto Lor, SDN Ciberem dengan 
jumlah siswa sebanyak 100 orang.

Proses pengumpulan data di lapangan, peneliti menggunakan teknik observasi atau pengamatan langsung di lapangan. Ali (2011) menjelaskan bahwa observasi adalah proses pengumpulan data yang dilakukan melalui pengamatan secara cermat dan teliti. Pada penelitian ini, pengamatan yang dilakukan yaitu melakukan pengamatan keterampilan yang dilakukan oleh sampel dengan menggunakan istrumen tes keberbakatan olahraga metode Australian Sport Search.

Prosedur metode Australian Sports Search, Hamlets (2007) yang memaparkan mengenai 10 tugas yang harus dilakukan yaitu 1) Tinggi Badan, 2) Tinggi Duduk, 3) Berat Badan, 4) Panjang Lengan, 5) Sprint $40 \mathrm{~m}, 6$ ) Kelincahan, 7) Multi Stage Fitness Test (MFT), 8) Koordinasi (Lempar tangkap bola), 9) Loncat Tegak dan 10) Basketball Throw. Setelah data diperoleh melalui observasi barulah data tersebut diolah dan dianalisis menggunakan teknik statistik untuk memperoleh data hasil penelitian. Analisis data menggunakan Penilaian Acuan Patokan (PAP) dari hasil tes keberbakatan yang dilakukan oleh sampel. Kemudian akan diketahui tingkat keberbakatan siswa dan jenis olahraga yang sesuai pada masing-masing sampel.

\section{HASIL}

Hasil dari pengolahan dan analisis data identifikasi keberbakatan olahraga anak Sekolah Dasar di Kabupaten Banyumas menggunakan metode Australian Sport Search terdapat pada tabel 1 di bawah ini:

Tabel 1 Hasil Keberbakatan Olahraga pada Anak Sekolah Dasar di Kabupaten Banyumas

\begin{tabular}{lcc}
\hline Kategori & Jumlah Siswa & Jumlah Siswa dalam \% \\
\hline Berbakat & 43 & $43 \%$ \\
\hline Kurang Berbakat & 57 & $57 \%$ \\
\hline Jumlah Total & 100 & $100 \%$ \\
\hline
\end{tabular}

Bedasarkan tabel tersebut menunjukan bahwa dari 100 anak Sekolah Dasar yang diteliti tingkat keberbakatan olahraga, sebanyak $43 \%$ anak memiliki bakat yang potensil untuk dikembangkan di tahap berikutnya, dan sebanyak $57 \%$ anak kurang atau tidak memiliki bakat yang baik dibidang olahraga. Hasil keberbakatan olahraga pada anak Sekolah Dasar di Kabupaten Banyumas juga menunjukan keberagaman jenis cabang olahraga yang dimiliki oleh anak. 


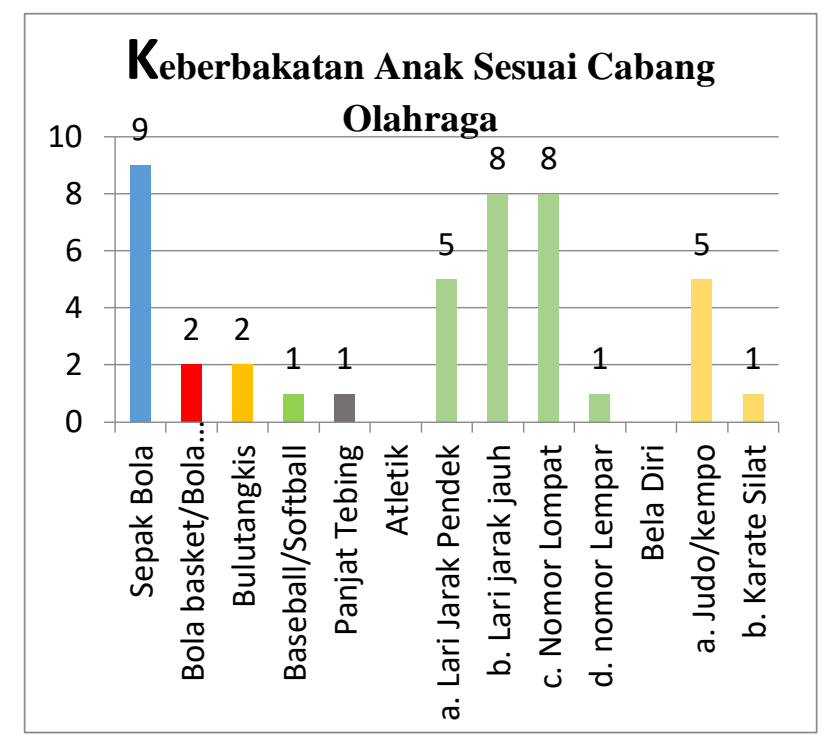

Grafik 1. Keberbakatan Anak Sesuai Cabang Olahraga Metode Australian Sport Search

Berdasarkan data di atas maka dapat digambarkan bahwa keberbakatan siswa Sekolah Dasar di Kabupaten Banyumas dari jumlah 43 anak memiliki keberagaman, diantaranya Sepak bola 9 anak, bola basket/bola tangan 2 anak, bulutangkis 2 anak, baseball/softball 1 anak, panjat tebing 1 anak, atletik 22 anak dan beladiri 6 anak.

\section{PEMBAHASAN}

Data tersebut menunjukan bahwa anak usia Sekolah Dasar di Kabupaten Banyumas memiliki bakat yang cukup baik di bidang olahraga, walaupun dari hasil penelitian menunjukan bahwa jumlah anak yang kurang berbakat di bidang olahraga lebih banyak dibandingkan anak yang berbakat. Hal ini dapat terjadi karena berbagai faktor, salah satunya yaitu belum diterapkannya program pembinaan olahraga jangka panjang yang tepat dan diimbangi dengan penerapan identifikasi bakat olahraga sejak dini. Ratno \& Nidyatama (2019) menjelaskan pembinaan olahraga untuk menghasilkan atlet yang berprestasi memerlukan waktu yang panjang serta didukung dengan metode melatih yang tepat. Oleh karrena itu, program identifikasi bakat olahraga harus dilakukan sejak dini sehingga dapat dilatih sesuai kemampuan yang dimiliki. Lebih lanjut Pambudi (2017) Identifikasi keberbakatan cabang olahraga merupakan cara yang dapat dilakukan untuk mengidentifikasi potensi dalam cabang olahraga tertentu, sehingga bakat anak yang telah teridentifikasi dapat disalurkan dalam olahraga prestasi.

Untuk dapat memaksimalkan potensi keberbakatan yang dimiliki anak, guru penjas yang bekerjasama dengan sekolah, dinas dan praktisi olahrga lainnya harus menciptakan proses pembelajaran penjas yang sesuai tahap pertumbuhan dan perkembangan anak, khususnya pada tahapan anak Sekolah Dasar harus diberikan materi yang dapat mengembangkan semua keterampilan dan kreatifitas anak, sehingga anak memiliki pengalaman gerak yang luas sebagai bekal untuk tahapan usia selanjutnya. 
Aktivitas fisik dan olahraga memiliki peran positif dalam peningkatan kemampuan belajar siswa, dan akan membuat anak lebih sehat (Budi, Hidayat, et al., 2019). Dengan melakukan rutinitas yang terprogram serta disesuaikan dengan pertumbuhan dan Perkembangan anak, akan membuat anak terhindar dari berbagai macam penyakit kurang bergerak (hipokinetik).

Tipe atau jenis aktivitas yang dapat diberikan kepada anak usia sekolah dasar 7-12 tahun yaitu keterampilan gerak multilateral dan keterampilan gerak dasar (fundamental movement). Pembelajaran pendidikan jasmani di sekolah dasar harus menerapkan konsep multilateral pada materi yang diajarkan kepada siswa, dengan keterampilan gerak dasar yang bervariasi maka anak dapat melakukan berbagai keterampilan olahraga dengan gerakan yang lebih kompleks (Budi, Kusuma, et al., 2019). Dalam Canadian Sport Centre (2007) dipaparkan hasil penelitian yang menunjukan bahwa anak-anak dan orang dewasa akan aktif dan bahkan mencpai prestasi puncak pada olahraga apabila pembinaan olahraga disesuai dengan tahapan pertumbuhan dan perkembnagan. Terdapat tujuh tahapan dasar pada pola pembinaan olahraga berdasarkan model Long Term Athletes Development (LTAD) yaitu:

a) Tahap 1: Active Start (0-6 Tahun)

b) Tahap 2: Fundamental (perempuan 6-8, laki-laki 6-9)

c) Tahap 3: Belajar untuk berlatih (perempuan 8-11, laki-laki 9-12)

d) Tahap 4: Latihan untuk berlatih (perempuan 11-15, laki-laki 12-16)

e) Tahap 5: Latihan untuk bertanding (perempuan 15-21, laki-laki 16-23)

f) Tahap 6: Latihan untuk menjadi juara (perempuan 18+, laki-laki 19+)

g) Tahap 7: Gaya hidup aktif berolahraga (semua umur)

Berlandaskan dari ilmu pengetahuan, penelitian, dan pengalaman untuk mencapai prestasi yang tinggi dalam olahraga adalah dengan melakukan latihan yang benar pada waktu yang tepat. Tujuh tahapan pengelompokkan berdasarkan karakteristik pertumbuhan dan perkembangan tersebut dapat dijadikan landasan bagi para praktisi olahraga untuk membuat suatu program, baik pembelajaran (pendidikan olahraga) maupun pelatihan (prestasi olahraga) secara efektif dan efisien.

Selain jenis materi yang diberikan, potensi olahrga anak juga dipengaruhi oleh fasilitas olahraga yang dimiliki oleh sekolah atau lembaga pendidikan lainnya. Gallahue et al. (2013) menjelaskan bahwa sarana bermain juga memfasilitasi pertumbuhan kognitif dan afektif pada anak-anak dan melalui media bermain, anak-anak prasekolah mengembangkan berbagai gerak fundamental anak diantaranya stabilitas, lokomotor dan kemampuan manipulatif.

Berdasarkan data penelitian tersebut maka dapat disimpulkan bahwa anak Sekolah Dasar di Kabupaten Banyumas memiliki potensi di berbagai cabang olahraga, baik cabang olahraga sepak bola, bola basket, bola tangan, bola voli, softball/baseball, atletik maupun beladiri. Hal ini menunjukan potensi yang cukup baik untuk perkembangan olahrga di Kabupaten Banyumas, karena dengan teridentifikasinya bakat olahraga pada anak secara tepat, maka pada tahap perkembangan selanjutnya anak tersebut dapat diarahkan sesuai cabang olahraga yang menjadi bakatnya. 
Apabila keberbakatan anak dapat diidentifikasi secara dini, pada tahap spesifikasi cabang olahraga maka guru, pelatih maupun lembaga terkait dapat mengarahkan anak tersebut dengan tepat dan hasil prestasi olahrga di Kabupaten Banyumas dapat meningkat karena memiliki banyak atlet-atlet muda potensial sesuai cabang olahraga yang telah teridentifikasi sejak dini. Akan tetapi, bakat yang dimiliki oleh anak belumlah cukup untuk menjamin bahwa anak dengan bakat yang bagus akan menjadi atlet juara di kemudian hari, Lawrence (2010) menjelaskan bahwa bakat fisik mungkintidak cukup untuk dapat membantu atlet untuk berprestasi tinggi di olahraga, akan tetapi perpaduan antara bakat dan program latihan yang tepat dapat membantu untuk memperoleh prestasi tersebut. Oleh karena itu, bakat yang baik harus didukung dengan pemberian program pembelajaran dan latihan yang sesuai, sehingga dapat memaksimalkan bakat olahrga yang dimiliki anak.

\section{SIMPULAN}

Hasil identifikasi keberbakatan olahraga anak Sekolah Dasar di Kabupaten Banyumas memiliki tingkat yang cukup baik, ini terbukti dengan jumlah anak yang berbakat yaitu sebanyak 43 anak. Berdasarkan hasil analisis keberbakatan olahraga dengan metode Australian Sport Search, anak Sekolah Dasar sebagian besar memiliki bakat olahraga di cabang olahraga sepak bola, beladiri dan atletik. Hasil tersebut menunjukan bahwa Kabupaten Banyumas memiliki potensi yang baik untuk mengembangkan ketiga cabang olahraga tersebut sebagai cabang olahraga unggulan di Kabupaten Banyumas, untuk dapat berprestasi tinggi di berbagai level kejuaraan, baik daerah, provinsi, nasional maupun internasional.

Dengan teridentifikasinya bakat-bakat olahraga pada anak Sekolah Dasar secara lebih dini, diharapkan guru, pelatih dan praktisi olahraga dapat menerapkan program pemanduan bakat olahraga untuk meningkatkan kualitas olahraga di Kabupaten Banyumas karena anak-anak usia dini telah teridentifikasi keberbakatan olahrga yang dimilikinya, tahap selanjutnya yaitu memberikan pola latihan yang sesuai untuk mendukung perkembangan bakat yang maksimal.

Rekomendasi bagi penelitian selanjutnya yaitu dapat dilakukan penelitian dengan sampel yang lebih banyak dan menambahkan beberapa kriteria di dalamnya, seperti jenis kelamin, usia, jenjang kelas atau sekolah yang lebih tinggi, daerah pedesaan, perkotaan dan pesisir pantai, selain itu juga dapat membandingkan instrument tes yang digunakan sehingga diketahui jenis tes identifikasi keberbakatan olahrga yang lebih baik untuk mengetahui tingkat keberbakatan olahraga pada anak.

\section{REFERENSI}

Ali, M. (2011). Memahami Riset Prilaku Dan Sosial. CV Pustaka Cendikia Utama.

Arifin, Z., Fallo, I. S., \& Sastaman, P. (2017). Identifikasi bakat olahraga siswa sekolah dasar di Pontianak 
Barat. Jurnal Pendidikan Olahraga.

Budi, D. R., Hidayat, R., \& Febriani, A. R. (2019). The Application of Tactical Approaches in Learning Handballs. JUARA : Jurnal Olahraga. https://doi.org/10.33222/juara.v4i2.534

Budi, D. R., Kusuma, M. N. H., Syafei, M., \& Stephani, M. R. (2019). The Analysis of Fundamental Movement Skill in Primary School Student in Mountain Range. https://doi.org/10.2991/icsshpe18.2019 .56

Canadian Sport Centre. (2007). Canadian Sport For Life. A Sport Parent's Guide. Canadian Sport Centres.

Furqon, M. H. (2000). Pengembangan Bakat Olahraga. Pusat Penelitian dan Pengembangan Keolahragaan (PUSLITBANG-OR) UNS.

Gallahue, D. L., Ozmun, J. C., \& Goodway, J. C. (2013). Compreendendo o desenvolvimento motor: bebês, crianças, adolescentes e adultos. In AMGH Editora Ltda.

Hamlets, T. (2007). Sports Search Health and Physical Activity Report. The London Borough of Tower Hamlets.

Hidayatullah, F., \& Sapta. (2008). Olahraga Usia Dini Dan Pemanduan Bakat. Kementerian Negara Pemuda Dan Olahraga Republik Indonesia.

Indarto, P., Subekti, N., \& Sudarmanto, E. (2018). Pengukuran Tingkat Minat Dengan Bakat Mahasiswa Pendidikan Olahraga Universitas Muhammadiyah Surakarta. Journal of Sport and Exercise Science, 1(2), 57-61.

Kusuma, M. N. H., Syafei, M., \& Budi, D. R. (2019). Biomekanika Olahraga. Unsoed Press.

Lawrence, I. (2010). Talent identification in soccer: A critical analysis of contemporary psychological research. Soccer Journal.

Pambudi, P. S. (2017). Identifikasi Tingkat Keberbakatan Cabang Olahraga Pada Siswa Usia 12-13 Tahun SMP Negeri 2 Galagah Suku Using Kabupaten Banyuwangi Tahun Pelajaran 2016/2017. Jurnal Kejaora, 2(1), 90-95.

Ratno, P., \& Nidyatama, N. (2019). Analisis Hasil Talent Scouting Dispora Kota Medan Cabang Olahraga Karate Pada Calon Atlet PPLD Kota Medan. Sains Olahraga: Jurnal IImiah IImu Keolahragaan. https://doi.org/10.24114/so.v3i1.13060

Sugiyono, P. D. (2016). metode penelitian kuantitatif, kualitatif,dan R\&D. In Alfabeta, cv. Alfabeta.

UU SKN. (2005). Undang-Undang Republik Indonesia Nomor 3 Tahun 2005. Republik Indonesia. 